\title{
Sea grapes powder with addition of tempe rich in collagen: An
}

\section{anti-aging functional food [version 1; peer review: 1 approved}

\section{with reservations]}

\author{
Happy Kurnia Permatasari(iD), Fahrul Nurkolis (iD), Christopherous Diva Vivo(iD3, \\ Sutamara Lasurdi Noor', Rahmawati Rahmawati (i)5, Son Radu6, \\ Hardinsyah Hardinsyah7, Nurpudji Astuti Taslim (iD), Nelly Mayulu (iD) \\ Defny Silvia Wewengkang (Did), Mury Kuswari11, Siti Chairiyah Batubara5, \\ William Ben Gunawan (D12, Maizer Said Nahdi2
}

\footnotetext{
${ }^{1}$ Department of Biochemistry and Biomolecular, Faculty of Medicine, Brawijaya University, Malang, 65145, Indonesia ${ }^{2}$ Department of Biological Sciences, Faculty of Sciences and Technology, State Islamic University of Sunan Kalijaga, Yogyakarta, 55281, Indonesia

${ }^{3}$ Dentistry, University of Indonesia, Depok, 16424, Indonesia

${ }^{4}$ Clinical and Public Health Nutrition Programme, University College London, London, WC1E 6BT, UK

${ }^{5}$ Food Technology Department, Sahid University of Jakarta, South Jakarta, 12870, Indonesia

${ }^{6}$ Food Sciences, Faculty of Human Ecology, Universiti Putra Malaysia, Serdang Selangor Darul Ehsan, 43400, Malaysia

${ }^{7}$ Applied Nutrition, Faculty of Human Ecology, IPB University, Bogor, 16680, Indonesia

${ }^{8}$ Clinical Nutrition, Faculty of Medicine, Hasanuddin University, Makassar, 90245, Indonesia

${ }^{9}$ Nutrition and Food, Faculty of Medicine, Sam Ratulangi University, Manado, 95115, Indonesia

${ }^{10}$ Pharmacy department, Faculty of Mathematics and Sciences, Sam Ratulangi University, Manado, 95115, Indonesia

${ }^{11}$ Nutrition Department, Faculty of health sciences, Universitas Esa Unggul, Jakarta, 11510, Indonesia

${ }^{12}$ Nutrition Sciences Department, Faculty of Medicine, Diponegoro University, Semarang, 50275, Indonesia
}

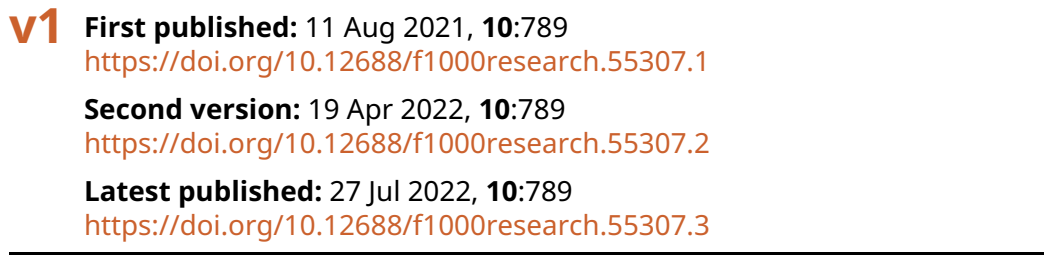

\section{Abstract}

Background: This study aimed to determine the potential anti-aging effects of sea grapes and tempe (Fermented soybeans) collagen particle size, by measuring the activities of anti-glycation, antioxidant and tyrosinase inhibitors. Methods: Collagen was isolated from sea grapes and tempe freeze dried powder and treated with different $\mathrm{NaOH}$ concentrations $(0.10 \mathrm{M} ; 0.20 \mathrm{M} ; 0.30 \mathrm{M})$, and $\mathrm{CH}_{3} \mathrm{COOH} 1 \mathrm{M}$ solution, separately. The collagen particle size was adjusted by stirring at $1000 \mathrm{rpm}$ for 5 and 10 hours. 2,2-diphenyl-1-picrylhydrazyl (DPPH) was used to measure the antioxidant activity, and L-tyrosine and LDOPA (I-3,4-dihydroxyphenylalanine) were used as a marker of tyrosine inhibition. Results: The collagen treated with $0.10 \mathrm{M} \mathrm{NaOH}$ produced the highest collagen yield (11.65\%), and largest particle size

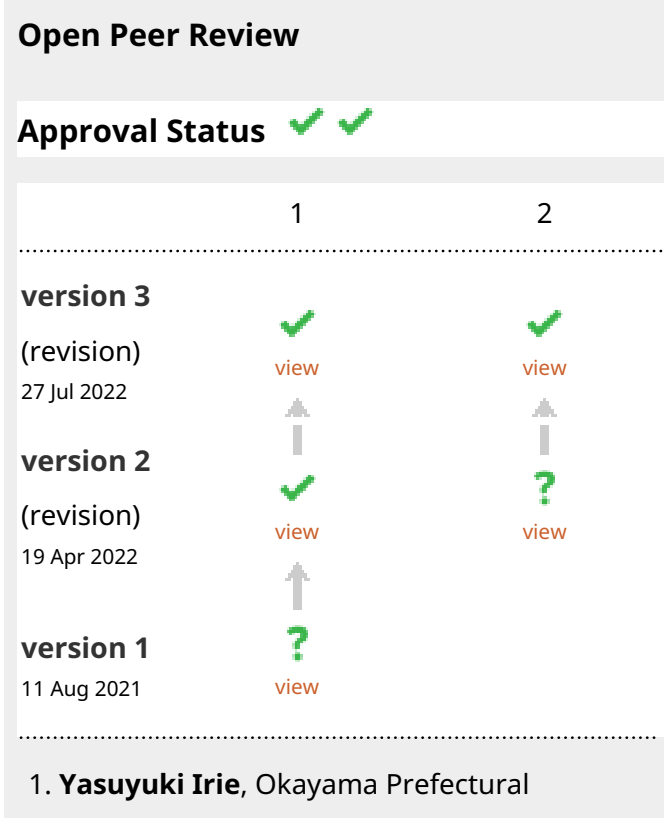

Page 1 of 11 
(2455 nm). Additionally, this collagen, when treated for 5 hours, exhibited $24.70 \%$ antioxidant activity, $62.60 \%$ anti-glycation, $8.97 \%$ Ltyrosine, and $26.77 \%$ L-Dopa inhibition activities. Meanwhile, the collagen treated for 10 hours had a $9.98 \%$ antioxidant activity, $41.48 \%$ anti-glycation, $7.89 \%$ L-tyrosine, and $2.67 \%$ L-Dopa inhibition activity. Conclusion: Sea grapes and tempe collagen powder treated with 0.10 $\mathrm{M} \mathrm{NaOH}$ and stirred for 5 hours, as functional foods have anti-aging properties.

\section{Keywords}

Ageing, antioxidant, sea grapes, tempe, functional food

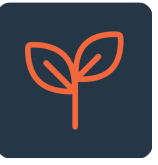

This article is included in the Agriculture, Food and Nutrition gateway.

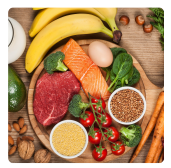

This article is included in the The Role of

\section{Nutrition in Healing and Improving Health}

collection.
University, Okayama, Japan

2. Manoj Kumar ID, Okayama Prefectural

University, Okayama, Japan

Okayama Prefectural University, Okayama, Japan

Vijay Sheri, Okayama Prefectural University, Okayama, Japan

Any reports and responses or comments on the article can be found at the end of the article.

Corresponding authors: Happy Kurnia Permatasari (happykp@ub.ac.id), Fahrul Nurkolis (20106040012@student.uin-suka.ac.id), Nelly Mayulu (nellymayulu@gmail.com)

Author roles: Permatasari HK: Conceptualization, Formal Analysis, Methodology, Writing - Original Draft Preparation; Nurkolis F: Conceptualization, Formal Analysis, Investigation, Project Administration, Visualization, Writing - Original Draft Preparation; Vivo CD: Formal Analysis, Writing - Original Draft Preparation; Noor SL: Formal Analysis, Writing - Original Draft Preparation; Rahmawati R: Formal Analysis, Supervision, Validation, Writing - Original Draft Preparation; Radu S: Supervision, Validation, Writing - Review \& Editing; Hardinsyah H: Supervision, Validation, Writing - Review \& Editing; Taslim NA: Formal Analysis, Supervision, Validation, Writing Original Draft Preparation, Writing - Review \& Editing; Mayulu N: Investigation, Methodology, Supervision, Writing - Review \& Editing; Wewengkang DS: Investigation, Methodology, Supervision, Validation, Writing - Original Draft Preparation; Kuswari M: Formal Analysis, Writing - Original Draft Preparation; Batubara SC: Conceptualization, Supervision, Writing - Review \& Editing; Gunawan WB: Visualization, Writing - Original Draft Preparation; Nahdi MS: Supervision, Writing - Review \& Editing

Competing interests: No competing interests were disclosed.

Grant information: The author(s) declared that no grants were involved in supporting this work.

Copyright: @ 2021 Permatasari HK et al. This is an open access article distributed under the terms of the Creative Commons Attribution License, which permits unrestricted use, distribution, and reproduction in any medium, provided the original work is properly cited.

How to cite this article: Permatasari HK, Nurkolis F, Vivo CD et al. Sea grapes powder with addition of tempe rich in collagen: An anti-aging functional food [version 1; peer review: 1 approved with reservations] F1000Research 2021, 10:789 https://doi.org/10.12688/f1000research.55307.1

First published: 11 Aug 2021, 10:789 https://doi.org/10.12688/f1000research.55307.1 


\section{Introduction}

Unhealth diet and excessive exposure to UV (ultra-violate) light can cause premature skin aging, leading to excess melanin production (hyperpigmentation), and darker patches (depigmentation) (Saeedi et al., 2019). Excessive UV light exposure can trigger oxidative stress, causing damage and apoptosis in skin cells. Oxidative stress occurs due to the increased intercellular levels of reactive oxygen species (ROS), which play an important role in pathogenesis of aging and chronic disorders (Peñalver et al., 2020; Park, 2013; Park et al., 2004). Consumption of high antioxidant functional foods in recent years has become popular as they can reduce oxidative stress damage. The presence of hydroxyl groups in antioxidant compounds acts as hydrogen donors to stabilize and prevent the formation of new ROS (Pereira et al., 2009).

In some Asian countries, such as Malaysia, Indonesia, and the Philippines, sea grapes or Caulerpa racemosa, which are edible marine macroalgae, are believed to be functional foods or nutraceuticals packed with antioxidant properties that can delay or prevent premature skin aging (Eren et al., 2019; Schumacker, 2015; Peñalver et al., 2020; Tanna et al., 2020; Yep et al., 2019; Pakki et al., 2020). Studies have explored several bioactive components in sea grapes, such as bioactive peptides, fibers (polysaccharides), polyphenols, flavonoids, antioxidants, and their distinctive compounds caulerpin (Cao et al., 2021; Yang et al., 2015; Yep et al., 2019). In line with this, sea grapes extract tested in diabetic rats indicated a lowering effect on glucose levels, reduced aspartate aminotransferase, and alanine aminotransferase activities, and a had a hepatoprotective effect (Qudus et al., 2020).

Similar to sea grapes, tempe (Fermented soyabeans), which is a local Indonesian food and known worldwide as a functional food, also has a high antioxidant activity (Kadar et al., 2020; Mani \& Ming, 2017).

Premature aging can be exacerbated by an unhealthy diet as well. High glucose levels at the presence of limited insulin can trigger the glycation process, whereby glucose is attached to the proteins, lipids, and DNA of the skin, producing Advanced Glycation End-products (AGEs) (Hantzidiamantis \& Lappin, 2019; Kim et al., 2017). Consequently, AGEs can deactivate the antioxidants, attack collagen, and elastyn, leaving the skin to lose moisture, become wrinkled, dull, and prone to damage and premature aging (Gill et al., 2019). Consumption of antioxidants and collagen, such as those found in sea grapes and tempeh, can inhibit AGEs (Aubry et al., 2020; Kadar et al., 2020; Yang et al., 2015).

Tyrosinase inhibition is another useful way of avoiding depigmentation. Tyrosinase transforms tyrosin to 3,4dihydroxyphenylalanine (DOPA), then transforms DOPA to dopakuinone; which results in melanin at the end of the process (Pillaiyar et al., 2017). As such this study aimed to determine the anti-aging potential effect of sea grapes and tempe collagen powder, by analyzing the activities of anti-glycation, antioxidant and tyrosinase inhibitors.

\section{Methods}

Sample preparation

Sea grapes (Caulerpa racemosa) were rinsed and cleaned with the use of $\mathrm{CO}_{2}$ free water. The soybean-based tempe is mixed with sea grapes $(0.25: 1)$ with a blender, and frozen at the $-22^{\circ} \mathrm{C}$ for 12 hours. Samples were dried with the use of freezer dryer (Lyovapor ${ }^{\mathrm{TM}} \mathrm{L}-200$ ) for 24 hours, which resulted in 0.3-0.5 mm powder.

\section{Water and ash content determination}

The determination of water content was based on the Association of Official Analytical Chemists (AOAC) drying method (Thermogravimetry) (Latimer, 2019) (Table 1), and the content was calculated by using the following formula:

$$
\text { Water content }(\%)=\frac{\mathrm{W} 1-\mathrm{W} 2}{\mathrm{~W} 1-\mathrm{W} 0} \times 100
$$

W0 = Weight of empty cup

W1 = Weight of the cup + initial sample (before heating in the oven)

$\mathrm{W} 2=$ Weight of cup + initial sample (after cooling in desiccator)

Table 1. Water and ash content.

\begin{tabular}{|l|l|}
\hline Ash (\%) & Water(\%) \\
\hline $2.65 \pm 0.50$ & $3.42 \pm 1.05$ \\
\hline
\end{tabular}


The procedure for determining the ash content was also with the use of the AOAC method (Latimer, 2019), and the content was calculated by using the following formula:

$$
\text { Ash content }(\%)=\frac{\text { Weight of bowl after heated }- \text { Constant weight of empty bowl }}{\text { Sample weight }} \times 100
$$

\section{Collagen isolation}

Collagen from sea grapes and tempe powder is isolated by treating the samples (ready-to-eat dry products) with three variations of $\mathrm{NaOH}$ concentrations $(0.10 \mathrm{M} ; 0.20 \mathrm{M} ; 0.30 \mathrm{M})$ with a ratio of $1: 10(\mathrm{w} / \mathrm{v})$, for 48 hours. The samples were then dried with the use of a freeze dryer (Lyovapor $\left.{ }^{\mathrm{TM}} \mathrm{L}-200\right)$ and treated with $1 \mathrm{M} \mathrm{CH}_{3} \mathrm{COOH}$ solution at a ratio of 1:10 (w/v), for 24 hours. Whatman filter paper (Grade 1) was used to obtain the filtrate. Lastly, the collagen obtained was once again dried with a freeze dryer.

\section{Collagen size reduction}

The optimal $\mathrm{NaOH}$ treated collagen is dissolved with distilled water $(1: 2(\mathrm{v} / \mathrm{v}))$ and spun for 5 and 10 hours with a magnetic stirrer $(1000 \mathrm{rpm})$ to establish size transformation. The size of the particles was measured by using the Particle Size Analyzer (PSA), and the antioxidant activity was tested with DPPH Assay (2,2-diphenyl-1-picrylhydrazyl), antiglycation, and tyrosinase inhibitors.

\section{Antioxidant activity measurement}

The enzyme-linked immunosorbent assay (ELISA, Sigma \#CS0790) was used to determine the antioxidant activity of DPPH (Batubara et al., 2015). $100 \mu \mathrm{L}$ of each sample along with $100 \mu \mathrm{L}$ of DPPH $(0.3 \mathrm{mM})$ was added to the 96 -well microplate and incubated for 30 minutes in a dark room. The absorbance was measured by using an ELISA reader at a wavelength of $517 \mathrm{~nm}$ (Underlying data) (Nurkolis, 2021). The antioxidant activity is calculated as follows:

$$
\text { Inhibition }(\%)=\frac{(\mathrm{A} 0-\mathrm{A} 1)}{\mathrm{A} 0} \times 100 \%
$$

$\mathrm{A} 0=$ Absorbance of blank

A1 = Absorbance of standard or sample

Anti-glycation activity measurement

The anti-glycation measurement (Table 2) was carried out as previously described (Povichit et al., 2010) (Underlying data) (Nurkolis, 2021). All the test solutions were incubated at $60^{\circ} \mathrm{C}$ for 40 hours. After incubation, the aliquots $(100 \mu \mathrm{L})$ were pipette into a 96-well plate. The relative amount of glycated Bovine Serum Albumin (BSA) was measured using a fluorometer at an excitation wavelength of $370 \mathrm{~nm}$, and emission of $440 \mathrm{~nm}$.

Tyrosinase inhibitory activity measurements

The tyrosinase enzyme inhibitory activity was measured as previously described (Batubara et al., 2015). L-tyrosine and L-DOPA (1-3,4-dihydroxyphenylalanine) were used as substrates (MyBioSource \#MBS9301852), and kojic acid as positive controls (Table 5) (Underlying data) (Nurkolis, 2021). Samples were dissolved with dimethyl sulfoxide (DMSO) as stock solution. The concentration variant was prepared by dissolving collagen with a phosphate buffer ( $\mathrm{pH}$ of 6.5).

\section{Table 2. The composition of the solution in the anti-glycation activity test.}

\begin{tabular}{|l|l|l|l|l|}
\hline Materials & $\begin{array}{l}\text { Solution A } \\
\text { (Glycation } \\
\text { control) } \\
(\mu \mathrm{L})\end{array}$ & $\begin{array}{l}\text { Solution B } \\
\text { (Control } \\
\text { corrector) } \\
(\mu \mathrm{L})\end{array}$ & $\begin{array}{l}\text { Solution C } \\
(\text { Sample) } \\
(\mu \mathrm{L})\end{array}$ & $\begin{array}{l}\text { Solution D } \\
\text { (Sample } \\
\text { corrector) } \\
(\boldsymbol{\mu} \mathrm{L})\end{array}$ \\
\hline $\begin{array}{l}\text { Phosphate buffer } 200 \mathrm{mM} \text { pH } 7.4 \mathrm{KH}_{2} \mathrm{PO}_{4} 0.2 \mathrm{M}+ \\
\mathrm{K}_{2} \mathrm{HPO}_{4} 0.2 \mathrm{M} \text { in distilled water) }\end{array}$ & 200 & 200 & 200 & 200 \\
\hline $\mathrm{BSA} 20 \mathrm{mg} / \mathrm{mL}$ & 80 & 80 & 80 & 80 \\
\hline Glucose $235 \mathrm{mM}$ & 40 & - & 40 & - \\
\hline Fructose $235 \mathrm{mM}$ & 40 & - & 40 & - \\
\hline Extract/Aminoguanidin & - & - & 80 & 80 \\
\hline
\end{tabular}


A total of $70 \mu \mathrm{L}$ of solution along with $30 \mu \mathrm{L}$ of tyrosinase enzyme (Sigma, 333 units $\mathrm{mL}^{-1}$ in phosphate buffer solution was added) was pippeted into the 96-well plate, and the mixture was incubated for 5 minutes. To this mixture, $110 \mu \mathrm{L}$ of substrate (L-tyrosine $2 \mathrm{mM}$ ) was added and incubated at $37^{\circ} \mathrm{C}$ for 30 minutes. The absorbance was measured at a wavelength of $492 \mathrm{~nm}$, by using the microplate reader (Spectrophotometer).

\section{Data analysis}

Statistical analyses were performed by using SPPS 26.0 for the Windows version. The differences between samples are analysed based on the antioxidant activity, anti-glycation activity, and tyrosinase inhibition activity tests. The data obtained from three replications (triples) were analyzed by ANOVA at 95\% CI ( $<<0.05)$. The result is defined as significant if the p-value is $<0.05$.

\section{Results}

Ash and water contents

Table 1 shows the triplicate process resulted in $3.42( \pm 1.05 \%)$ water content and $2.65( \pm 0.50 \%)$ ash content.

\section{Collagen yield}

Collagen yield obtained by each concentration is shown in Table 3 . The isolation with $\mathrm{NaOH} 0.10 \mathrm{M}$ produced the highest collagen yield $(\mathrm{p}<0.05)$, this showed that there was a significant difference in the yield of the three variations of $\mathrm{NaOH}$ and $\mathrm{CH} 3 \mathrm{COOH}$ treatment. Levenes' test of homogeneity of variants was $\mathrm{p}=0.397(\mathrm{p}>0.05)$.

\section{Collagen particle size}

Particle Size Analyzer (PSA) was used to determine the collagen particles size. The collagen yields ranged from $1012 \mathrm{~nm}$ to $2455 \mathrm{~nm}$, with the highest DPPH and glycation inhibitions at $2455 \mathrm{~nm}(11.74 \%$ and $62.76 \%$, respectively) (Table 4). In addition to producing significantly different yields, different treatments across the three samples were also significantly different in the particles size $(\mathrm{p}=0.000)$, with $\mathrm{p}>0.05$ homogeneity. The collagen with the largest particle size of $2455 \mathrm{~nm}$ was obtained from $0.10 \mathrm{M} \mathrm{NaOH}$ treatment for 5 hours (Table 4).

Antioxidant, anti-glycation and tyrosinase inhibitor activity

The $0.10 \mathrm{M} \mathrm{NaOH}$ treatment for 5 hours, resulted in $24.70 \%$ and $62.60 \%$ antioxidant and anti-glycation activities, respectively (Table 4). However, treatment with $0.10 \mathrm{M} \mathrm{NaOH}$ for 10 hours resulted in $9.98 \%$ antioxidant and $41.48 \%$ anti-glycation activities. Additionally, treatment with $0.10 \mathrm{M} \mathrm{NaOH}$ for 5 hours inhibited $8.97 \%$ of L-tyrosine and $26.77 \%$ of L-Dopa activities (Table 5).

\section{Discussion}

Based on the ash and water content analysis, the powder made from sea grapes and tempe is considered safe to consume, based on the Indonesia National Standard (SNI) No. 01-4320-1996 regulations for food in powder form or

Table 3. Yield of isolated collagen with $\mathrm{NaOH}$ and $\mathrm{CH}_{3} \mathrm{COOH}$ variations

\begin{tabular}{|l|l|}
\hline $\mathrm{NaOH}+\mathrm{CH}_{3} \mathrm{COOH}$ concentrations (M) & Collagen yields (\%) \\
\hline 0.10 & 11.65 \\
\hline 0.20 & 8.70 \\
\hline 0.30 & 4.98 \\
\hline
\end{tabular}

Table 4. Particle size, antioxidant activity and glycation inhibition

\begin{tabular}{|l|l|l|l|}
\hline Collagen treatment & Particle size $(\mathbf{n m})$ & DPPH inhibition (\%) & Glycation inhibition (\%) \\
\hline $\mathrm{NaOH} \mathrm{0.10} \mathrm{M}$ & 2455 & $11.74^{*}$ & $62.76^{*}$ \\
\hline $\mathrm{NaOH} \mathrm{0.20} \mathrm{M}$ & 1012 & $8.13^{*}$ & $42.50^{*}$ \\
\hline $\mathrm{NaOH} \mathrm{0.30} \mathrm{M}$ & 1922 & $12.39^{*}$ & $57.43^{*}$ \\
\hline $\mathrm{NaOH} \mathrm{0.10} \mathrm{M} \mathrm{(5} \mathrm{Hours)}$ & 1482 & $24.70^{*}$ & $62.60^{*}$ \\
\hline $\mathrm{NaOH} \mathrm{0.10} \mathrm{M} \mathrm{(10} \mathrm{Hours)}$ & 1568 & $9.98^{*}$ & $41.48^{*}$ \\
\hline
\end{tabular}

*Shows significant difference at $p=0.05$. 
Table 5. Anti-tyrosinase activity of collagen at $1000 \mathrm{mg} / \mathrm{L}$.

\begin{tabular}{|l|l|l|}
\hline Collagen & Tyrosinase inhibition by substrate (\%) \\
& L-Tirosina & L-Dopa \\
\hline $\mathrm{NaOH} 0.10 \mathrm{M}$ (5 Hours) & 8.97 & $26.77^{*}$ \\
\hline $\mathrm{NaOH} 0.10 \mathrm{M}$ (10 Hours) & 7.89 & $2.67^{*}$ \\
\hline
\end{tabular}

Kojic Acid IC $50: 8.90 \mathrm{mg} / \mathrm{L}$.

*Shows significant difference at $p=0.05$.

powder extract (3\% maximum water content). Moreover, pre-treatment was done to remove the non-collagen proteins, as well as assessing the amount of pure collagen proteins in the final product. Collagen is usually insoluble in alkaline solutions, however, $\mathrm{NaOH}$ treatment is commonly used in the collagen extraction process as it can significantly minimize collagen loss, compared to other alkaline solutions (Liu et al., 2015). In this study collagen from sea grapes and tempe powder treated with $0.10 \mathrm{M} \mathrm{NaOH}$ produced the highest yield, which showed the effectiveness of the extraction process. As indicated by Potaros and colleagues, the difference in yield can be caused by the extraction method, such as the concentration of a solution in the non-collagen protein separation process, and the type of material used (Potaros et al., 2009). Therefore, treatment with variations of $\mathrm{NaOH}$ concentration could affect the collagen yields $(\%)$, particle size, DPPH inhibition (\%) and anti-glycation produced (\%).

The collagen particle measurements in this study ranged from 1012 to $2455 \mathrm{~nm}$ (Table 4), which was too large to be considered as nanoparticles (10-1000nm) (Mohanraj \& Chen, 2007). Therefore, further optimization was carried out in order to reduce the collagen particle size of the $0.10 \mathrm{M} \mathrm{NaOH}$ treatment, through stirring for 5 or 10 hours. It is necessary to reduce the particle size in order to increase its absorption by the digestive system (Mohanraj \& Chen, 2007). In a study by Mohanrja et al., reducing the particle size should be through the hydrolysis process, and not by a mechanical process such as stirring, as it can re-solidify or coagulate the collagen (Mohanraj \& Chen, 2007). However, the hydrolysis process was avoided in this study, as it might have broken down other important compounds, such as antioxidants. Mechanical stirring for 5 hours, resulted in almost 2-fold reduction in the size of the collagen particles. However, stirring for 10 hours did not reduce the particle size due to the reasons described by Mohanraj et al. (2007).

The treatment with $0.10 \mathrm{M} \mathrm{NaOH}$ (Table 4), produced the largest particle size with the highest anti-glycation activity compared to other concentrations, however, its antioxidant activity was lower compared to $0.30 \mathrm{M} \mathrm{NaOH}$.

\section{collagen powder}

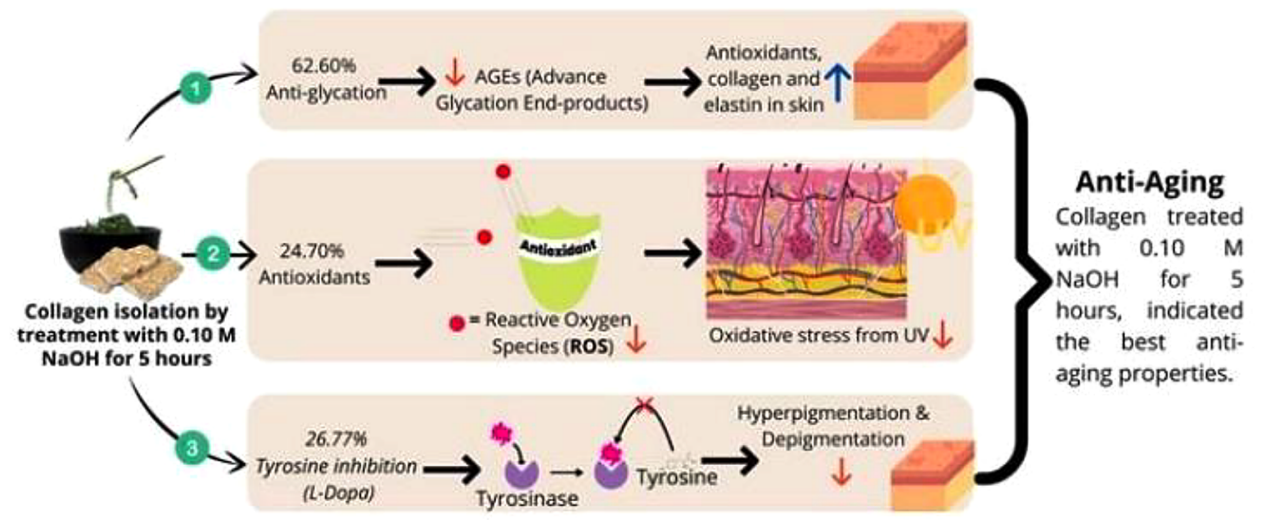

The anti-aging properties of the sea grapes and tempe collagen powder is determined through anti-glycation, antioxidation, and tyrosinase inhibition:

- Anti-glycation: the powder has $62.60 \%$ anti-glycation effect, and it can reduce AGEs.

- Antioxidants: the antioxidant activity of this powder is at $27.70 \%$ and it has the potential to neutralize ROS.

- Tyrosinase inhibition: the powder has $26.77 \%$ tyrosinase inhibition activity, and it may have the potential to prevent or delay hyperpigmentation and depigmentation processes caused by the UV light.

Figure 1. Anti-glycation, antioxidant, and tyrosinase inhibition of sea grapes and tempe collagen powder. 
The percentage of antioxidants produced is similar to commercial collagen $\left({ }^{\mathrm{IC}} 50\right)$, which is greater than the result in the study by Fauzi (2018). At $0.10 \mathrm{M} \mathrm{NaOH}$ treatment with 5 hours had a better anti-glycation activity than at 10 hours. The resulting anti-glycation activity was higher when compared to the $17.74 \%$ activity of the collagen produced in Fauzi dissertation research (Fauzi, 2018).

Excessive melanin production or hyperpigmentation caused by exposure to excessive UV rays can lead to dark skin or depigmentation (Saeedi et al., 2019). Tyrosine inhibition can reduce excessive melanin production, which can prevent skin damage. The results of this study showed that treating L-tyrosine and L-DOPA substrates for 5 hours had a greater tyrosinase enzyme inhibitory activity, compared with treatment for a longer period (Table 5) (Figure 1). In the Fauzi study, commercial collagen did not show tyrosinase enzyme inhibitory activity at $1000 \mathrm{mg} / \mathrm{L}$ and exhibited lower activity than the collagen obtained in the present study (Fauzi, 2018).

Sea grapes and tempe powder combined with a variety of food additives can be used by manufacturing companies as functional foods or anti-aging nutraceuticals, by $\mathrm{NaOH}(0.10 \mathrm{M})$ and $\mathrm{CH}_{3} \mathrm{COOH}(1 \mathrm{M})$ treatment at $1000 \mathrm{rpm}$ for 5 hours (Figure 1). However, this in vitro pilot study has the potential to be a basic reference for pre-clinical research. Further trials are needed to determine the continued efficacy of this study.

\section{Conclusion}

Sea grapes and tempe collagen powder as functional foods or nutraceuticals have anti-aging properties. Based on the antiglycation, anti-tyrosinase and antioxidant activities, the collagen of this powder treated with $0.10 \mathrm{M} \mathrm{NaOH}$ for 5 hours, has the most optimal anti-aging effect. Manufacturers seeking to produce anti-aging food products rich in collagen can use this method for determining the optimal powder formulation, however extensive trials are still needed to further analyze its clinical effects.

\section{Data availability}

Underlying data

Figshare: Sea grapes powder with addition of tempe rich in collagen: An anti-aging functional food.

DOI: https://doi.org/10.6084/m9.figshare.15072597.v3 (Nurkolis, 2021).

The project contains the following underlying data:

- Raw data: Water and ash content, antioxidant activity, glycation inhibition activity, particle size, anti-tyrosinase activity of the collagen. The chemical composition of the solution in the anti-glycation activity test.

Data are available under the terms of the Creative Commons Zero "No rights reserved" data waiver (CC0 1.0 Public domain dedication).

\section{Author contributions}

All authors contributed to the writing and revision of this article; and all authors have read and approved the final manuscript. H. K. P. and F. N. gathered study ideas, designed the experiments, analyzed data, and compiled manuscripts. N. A. T., H. H., N. S., M. K., S. R., R. R. and N. M. analyzed and interpreted data and critically revised the manuscript. The F. N., S. L. N., D. S. W. and H. K. P. conducted experiments, analyzed biochemistry, and critically revised the manuscript. N. M., S. C. B., W. B. G., and C.D.V., implemented experimental protocols, assisted in statistical analysis, interpreted data, and critically revised manuscripts. All writers read and approve the final manuscript.

\section{Acknowledgement}

We thank State Islamic University of Sunan Kalijaga; Faculty of Medicine-Brawijaya University and all of contributors for their outstanding help in formatting the paper. I would also like to express my gratitude to Prof. Ir. Hardinsyah, MS., Ph.D. (as President of the Federations of Asian Nutrition Societies; President of the Food and Nutrition Society of Indonesia; and Chair of Southeast Asia Probiotics Scientific and Regulatory Experts Network), and Prof. Dr. Nurpudji A Taslim, MD., MPH.,Sp.GK(K) (Chair of Indonesian Clinical Nutrition Physician Association), and also to Nindy Sabrina, S.Gz., M. Sc. who has provided comments, suggestions, and input in the research and writing of this paper, as well as the motivation he has given the writers to keep the passion for research during the pandemic. 
Aseervatham GSB, Sivasudha T, Jeyadevi R, et al.: Environmental factors and unhealthy lifestyle influence oxidative stress in humans--an overview. Environ Sci Pollut Res Int. 2013; vol. 20, no. 7: pp. 4356-4369. PubMed Abstract | Publisher Full Text

Aubry L, De-Oliveira-Ferreira C, Santé-Lhoutellier V, et al.: Redox Potential and Antioxidant Capacity of Bovine Bone Collagen Peptides towards Stable Free Radicals, and Bovine Meat Lipids and Proteins. Effect of Animal Age, Bone Anatomy and Proteases-A Step Forward towards Collagen-Rich Tissue Valorisation. Molecules (Basel, Switzerland). 2020; 25(22), 5422.

PubMed Abstract | Publisher Full Text | Free Full Text

Batubara I, Julita I, Darusman LK, et al.: Flower Bracts of Temulawak (Curcuma xanthorrhiza) for Skin Care: Anti-acne and Whitening Agents. Procedia Chem. Jan. 2015; 14: 216-224.

Publisher Full Text

Cao M, Li Y, Famurewa AC, et al:: Antidiabetic and Nephroprotective Effects of Polysaccharide Extract from the Seaweed Caulerpa racemosa in High Fructose-Streptozotocin Induced Diabetic Nephropathy. Diabetes Metab Syndr Obes. 2021; 14: 2121-2131.

PubMed Abstract | Publisher Full Text | Free Full Text

Eren B, Tuncay Tanrıverdi S, Aydın Köse F, et al.: Antioxidant properties evaluation of topical astaxanthin formulations as anti-aging products. J. Cosmet. Dermatol. Feb. 2019; 18(1): 242-250. PubMed Abstract | Publisher Full Text

Fauzi S: Hidrolisat Kolagen Kulit Ikan Tuna Sirip Kuning (Thunnus albacares) sebagai anti penuaan 2018. Accessed: Apr. 10, 2021 Reference Source

Gill V, Kumar V, Singh K, et al.: Advanced glycation end products (AGEs) may be a striking link between modern diet and health Biomolecules. MDPIAG; Dec. 01, 2019; vol. 9, no. 12.

PubMed Abstract | Publisher Full Text | Free Full Text

Hantzidiamantis PJ, Lappin SL: Physiology Glucose. StatPearls Publishing; 2019.

Kadar AD, Astawan M, Putri SP, et al.: Metabolomics-Based Study of the Effect of Raw Materials to the End Product of Tempe-An Indonesian Fermented Soybean. Metabolites. Sep. 2020; 10(9): 367 PubMed Abstract | Publisher Full Text | Free Full Text

Kim C-S, Park S, Kim J: The role of glycation in the pathogenesis of aging and its prevention through herbal products and physical exercise.

J. Exerc. Nutr. Biochem. Sep. 2017; 21(3): 55-61.

PubMed Abstract | Publisher Full Text | Free Full Tex

Latimer G: Official Methods of Analysis of AOAC INTERNATIONAL, 21st Edition. AOAC Int. 2019; no. 2019, pp. 2019-2022. Accessed: Mar. 28, 2021. Reference Source

Liu $D$, et al.: Effects of alkaline pretreatments and acid extraction conditions on the acid-soluble collagen from grass carp (Ctenopharyngodon idella) skin. Food Chem. Apr. 2015; 172: 836-843. PubMed Abstract | Publisher Full Text

Mani V, Ming LC: Tempeh and Other Fermented Soybean Products Rich in Isoflavones. Fermented Foods in Health and Disease Prevention. Elsevier Inc; 2017, pp. 453-474.

Publisher Full Tex

Mohanraj VJ, Chen Y: Nanoparticles - A review. Trop. J. Pharm. Res. Jul. 2007; 5(1): 561-573.

Publisher Full Text

Nurkolis F: Sea grapes powder with addition of tempe rich in collagen Potential as an anti-aging functional food.xlsx. figshare. Dataset. 2021. Publisher Full Text
Pakki E, Tayeb R, Usmar U, et al.: Effect of orally administered combination of Caulerpa racemosa and Eleutherine americana (Aubl) Merr extracts on phagocytic activity of macrophage. Res. Pharm. SCi. Aug. 2020; 15(4): 401-409.

PubMed Abstract | Publisher Full Text | Free Full Text

Park S, et al.: L-Ascorbic acid induces apoptosis in acute myeloid leukemia cells via hydrogen peroxide-mediated mechanisms. Int J. Biochem. Cell Biol. Nov. 2004; 36(11): 2180-2195.

PubMed Abstract | Publisher Full Text

Park S: The effects of high concentrations of vitamin C on cancer cells Nutrients. MDPI AG; Sep. 09, 2013; vol. 5, no. 9. pp. 3496-3505.

PubMed Abstract | Publisher Full Text | Free Full Text

Peñalver R, Lorenzo JM, Ros G, et al.: Seaweeds as a Functional Ingredient for a Healthy Diet. Mar Drugs. 2020; 18(6): 301.

PubMed Abstract | Publisher Full Text | Free Full Text

Pereira D, Valentão P, Pereira J, et al.: Phenolics: From Chemistry to Biology. Molecules. Jun. 2009; 14(6): 2202-2211.

Publisher Full Text | Free Full Text

Pillaiyar T, Manickam M, Namasivayam V: Skin whitening agents: Medicinal chemistry perspective of tyrosinase inhibitors J Enzyme Inhib Med Chem. Taylor and Francis Ltd; 2017; vol. 32, no. 1. pp. 403-425.

PubMed Abstract | Publisher Full Text | Free Full Text

Potaros T, Raksakulthai N, Runglerdkreangkrai J, et al.: Characteristics of Collagen from Nile Tilapia (Oreochromis niloticus) Skin Isolated by Two Different Methods 2009. Accessed: Apr. 10, 2021.

Reference Source

Povichit N, Phrutivorapongkul A, Suttajit M, et al.: Antiglycation and antioxidant activities of oxyresveratrol extracted from the heartwood of artocarpus Iakoocha roxb. Maejo Int. J. Sci. Technol. 2010; 4(3): 454-461. Accessed: Apr. 07, 2021.

Reference Source

Qudus A, Aroyehun B, et al.: Bioprospecting Cultivated Tropical Green Algae, Caulerpa racemosa (Forsskal) J. Agardh: A Perspective on

Nutritional Properties, Antioxidative Capacity and Anti-Diabetic Potential. Foods. Sep. 2020; 9(9): 1313.

PubMed Abstract | Publisher Full Text | Free Full Text

Saeedi M, Eslamifar M, Khezri K: Kojic acid applications in cosmetic and pharmaceutical preparations. Biomed Pharmacother. Elsevier Masson

SAS; Feb. 01, 2019; vol. 110, pp. 582-593.

PubMed Abstract | Publisher Full Text

Schumacker PT: Reactive Oxygen Species in Cancer: A Dance with the Devil Cancer Cell. Cell Press; Feb. 09, 2015; vol. 27, no. 2. pp. 156-157. PubMed Abstract | Publisher Full Text

Tanna B, Yadav S, Mishra A: Anti-proliferative and ROS-inhibitory activities reveal the anticancer potential of Caulerpa species. Mol. Biol. Rep. Oct. 2020; 47(10): 7403-7411.

PubMed Abstract | Publisher Full Text

Yang $\mathrm{P}$, et al.: Bioactive constituents from the green alga Caulerpa racemosa. Bioorganic Med. Chem. Jan. 2015; 23(1): 38-45.

PubMed Abstract | Publisher Full Text

Yap WF, Tay V, Tan SH, et al.: Decoding antioxidant and antibacteria potentials of Malaysian green seaweeds: Caulerpa racemosa and caulerpa lentillifera. Antibiotics. Sep. 2019; 8(3).

PubMed Abstract | Publisher Full Text | Free Full Text

Zhang S, Duan E: Fighting against Skin Aging: The Way from Bench to Bedside Cell Transplant. SAGE Publications Ltd; May 01, 2018; vol. 27, no. 5. pp. 729-738.

PubMed Abstract | Publisher Full Text | Free Full Text 


\section{Open Peer Review}

\section{Current Peer Review Status: ?}

\section{Version 1}

Reviewer Report 31 January 2022

https://doi.org/10.5256/f1000research.58871.r119984

(C) 2022 Irie $Y$. This is an open access peer review report distributed under the terms of the Creative Commons Attribution License, which permits unrestricted use, distribution, and reproduction in any medium, provided the original work is properly cited.

\section{Yasuyuki Irie}

Department of Nutritional Science, Faculty of Health and Welfare Science, Okayama Prefectural University, Okayama, Japan

The authors aimed to determine the anti-aging potential effect of sea grapes and tempe collagen powder, by analyzing the activities of anti-glycation, antioxidant and tyrosinase inhibition. In general, the article clearly and accurately presented the data and their interpretations citing the current literature.

As a in vitro pilot study, the study design is appropriate and the study has academic merit. Although I am not a specialist for food processing, the methods seem to be appropriate and can be replicated by other researchers. All the source data underlying the results available to ensure full reproducibility. The conclusions were drawn adequately and supported by the results.

One of the new findings they presented in this study is the development of a method to optimize the collagen particle size. Therefore, it is necessary to fully explain the significance of optimizing collagen particle size and the previous studies. That is the comment for the inquiry "Is the work clearly and accurately presented and does it cite the current literature?"

In the last part of the abstract, the authors assert that "Sea grapes and tempe collagen powder treated with $0.10 \mathrm{M} \mathrm{NaOH}$ and stirred for 5 hours, as functional foods have anti-aging properties." However, as stated in the last part of the Discussion in the text, this study was an "in vitro pilot study," and it cannot be concluded that functional foods have anti-aging properties. Therefore, the wording of the abstract should be changed appropriately. That is the comment for the inquiry "Are the conclusions drawn adequately supported by the results?"

Is the work clearly and accurately presented and does it cite the current literature? Partly

\section{Is the study design appropriate and is the work technically sound?}


Are sufficient details of methods and analysis provided to allow replication by others? Yes

If applicable, is the statistical analysis and its interpretation appropriate? Yes

Are all the source data underlying the results available to ensure full reproducibility? Yes

Are the conclusions drawn adequately supported by the results? Partly

Competing Interests: I collaborated with Professor Taslim on an article titled, Protein-Energy Nutritional Status of Moderately Low Protein Intake-Sago Diets Compared to Sufficiently Protein Intake-Rice Diets in Well-Nourished Lowlanders in Papua, Indonesia (https://f1000research.com/articles/11-138/v1). I am convinced that I have been fair in my peer review. I have not heard anything about the article concerned from my collaborator, Professor Taslim. Professor Taslim is neither the first nor the lead author of the paper. Therefore, I have no involvement in the planning or execution of this research. Professor Taslim has made significant contributions to our "Papua Study," particularly in the conduct of field research. However, the collaborative research relationship in this "Papua Study" is unrelated to the collaboration between Professor Taslim and the sea grape researchers, and I am neither a potential competitor nor a potential collaborator of theirs. I declare that I have had no contact with Professor Taslim between the time I was asked to review the manuscript and the time I submitted the report.

Reviewer Expertise: Pharmacology and Nutritional Science

I confirm that I have read this submission and believe that I have an appropriate level of expertise to confirm that it is of an acceptable scientific standard, however I have significant reservations, as outlined above. 
The benefits of publishing with F1000Research:

- Your article is published within days, with no editorial bias

- You can publish traditional articles, null/negative results, case reports, data notes and more

- The peer review process is transparent and collaborative

- Your article is indexed in PubMed after passing peer review

- Dedicated customer support at every stage

For pre-submission enquiries, contact research@f1000.com 